\title{
Effect of Service Quality on Post-Accreditation Outpatient Health Care Services: Case Study of the Sulewana Community Health Center in Poso Regency
}

\author{
Floranis Pradoso ${ }^{*}$, Muhammad Alwy Arifn², Saifuddin Sirajuddin ${ }^{3}$, Darmawansyah², Amran \\ Razak $^{2}$, Muhammad Syafar ${ }^{4}$ \\ ${ }^{\mathrm{T}}$ Master Program in Health Administration and Policy Department, Faculty of Public Health, Hasanuddin University, \\ Indonesia \\ ${ }^{2}$ Department of Health Administration and Policy, Faculty of Public Health, Hasanuddin University, Indonesia \\ ${ }^{3}$ Department of Nutrition, Faculty of Public Health, Hasanuddin University Indonesia \\ ${ }^{4}$ Department of Health Promotion and Behavioral Sciences, Faculty of Public Health, Hasanuddin University, Indonesia
}

*Corresponding Author

Floransi Pradoso

\author{
Article History \\ Received: 07.07.2020 \\ Accepted: 21.07 .2020 \\ Published: 26.07.2020
}

\begin{abstract}
The quality of health services is the degree of perfection of health services in accordance with professional standards and service standards using the potential resources available in hospitals or health centers in a reasonable, efficient, and effective manner. This study aims to determine the effect of service quality between perceptions and expectations on the quality of post-accreditation outpatient health care services in sulewana puskesmas (Community Health Center) Poso Regency. This study uses quantitative research methods with a cross-sectional study design. The population in this study were 25 health workers who provided health services in the outpatient unit of the sulewana puskesmas and all outpatients who came to visit the puskesmas of Sulewana were 6,526 in 2019. The sampling technique was done by accidental sampling. Data were collected through direct interviews using a research instrument in the form of a questionnaire. Data were analyzed univariately and bivariate. The results showed that there was an influence of physical evidence $(\mathrm{p}=0.003)$, reliability $(\mathrm{p}=0.004)$, and collateral $(\mathrm{p}=0.022)$ on the quality of post-accreditation outpatient health services in the sulewana health center in Poso Regency. It is expected that the health workers so that the procedure for admitting outpatients in the administration section of the Puskesmas Sulewana, Poso Regency will not be complicated (fast) and to further improve the quality of health services towards plenary accreditation, by further improving the quality of the tangibles dimension which impacts on chapter II, dimensions The reliability of impact in chapter I, and the assurance dimension impact on chapter III of the puskesmas accreditation standards.
\end{abstract}

Keywords: quality, service quality, outpatient, accreditation, puskesmas.

\section{INTRODUCTION}

Quality of health services is the degree of perfection of health services in accordance with professional standards and service standards by using the potential resources available in hospitals or health centers in a reasonable, efficient and effective manner and provided safely and satisfactorily according to norms, ethics, law, and socio-culture by taking into account the limitations and capabilities of the government, as well as the consumer community [1].

The main purpose of Puskesmas accreditation is to foster quality improvement, performance through continuous improvement of management systems, quality management systems, and service delivery systems and programs, and the application of risk management, and not just assessments to obtain accreditation certificates [2].

Secondary data from the Sulewana Health Center in Poso Regency, Central Sulawesi Province shows that the number of outpatient visits in 2018 was 6.306 patients, with an average monthly visit of 525 patients, and in 2019 the number of outpatient visits was 6,526 patients with an average monthly visit of 543 patient. In providing health services

Copyright @ 2020: This is an open-access article distributed under the terms of the Creative Commons Attribution license which permits unrestricted use, distribution, and reproduction in any medium for non commercial use (NonCommercial, or CC-BY-NC) provided the original author and source are credited. 
in the Sulewana Community Health Center, there is a lack of health workers (dentists and midwives), for facilities and infrastructure is still inadequate. The supply of drugs is still limited so that requires patients to buy drugs at the pharmacy[3].

The accreditation of a puskesmas (Community Health Center) cannot guarantee that the puskesmas does not have a problem in terms of the quality of health services. There is no concrete evidence that can show that all accredited puskesmas must have a better quality of service. The purpose of this study is to determine the effect of service quality between perceptions and expectations on the quality of post-accreditation outpatient health care services in Sulewana Puskesmas.

\section{METHODS}

This research uses quantitative research methods with a cross-sectional study design. The population in this study were 25 health workers who provided health services in the outpatient unit of the sulewana puskesmas and all outpatients who came to visit the puskesmas (Community Health Center) of Sulewana were 6,526 in 2019. The sampling technique was done by accidental sampling. Data were collected through direct interviews using a research instrument in the form of a questionnaire. Data were analyzed univariately and bivariate

\section{RESULTS}

Based on table 1 the characteristics of respondents by sex from 25 respondents of health workers, who are male as much as $1(4 \%)$ and women as much as 24 (96\%). While of the 329 patient respondents, there were 111 males (33.7\%) and 218 females $(66.3 \%)$. Characteristics of respondents based on the education of health workers, the most is S1 as many as $15(60 \%)$ and the least education is high school/equivalent as much as $1(4 \%)$. Whereas for education the most patients were SMA / equivalent as many as $205(62.3 \%)$ and the least education was SD as many as $10(3 \%)$.

Table-1: Frequency Distribution of Characteristics of Outpatient Respondents in Sulewana Health Center in 2020

\begin{tabular}{|c|c|c|}
\hline Sex & $\mathbf{N}$ & $\%$ \\
\hline \multicolumn{3}{|l|}{ Health Worker } \\
\hline Male & 1 & 4 \\
\hline Female & 24 & 96 \\
\hline Total & 25 & 100 \\
\hline \multicolumn{3}{|l|}{ Patient } \\
\hline Laki-laki & 111 & 33,7 \\
\hline Perempuan & 218 & 66,3 \\
\hline Total & 329 & 100 \\
\hline \multicolumn{3}{|l|}{ Education } \\
\hline Health Workers & & \\
\hline High School/Equivalent & 1 & 4 \\
\hline D.III & 39 & 36 \\
\hline Bachelor & 15 & 60 \\
\hline Total & & 100 \\
\hline Patient & & \\
\hline Elementary School & 10 & 3 \\
\hline Junior School/Equivalent & 39 & 11,9 \\
\hline High School/Equivalent & 205 & 62,3 \\
\hline Higher Education & 75 & 22,8 \\
\hline Total & 329 & 100 \\
\hline
\end{tabular}

Source: Primary Data, 2020 
Table-2: Influence of Research Variables on the quality of post-accreditation outpatient health services in Sulewana Puskesmas in Poso Regency

\begin{tabular}{|c|c|c|c|c|c|c|c|}
\hline \multirow[t]{3}{*}{ Research Variable } & \multicolumn{4}{|c|}{ Service Quality } & \multirow{2}{*}{\multicolumn{2}{|c|}{ Amount }} & \multirow[t]{3}{*}{$\mathbf{p}$} \\
\hline & \multicolumn{2}{|c|}{ Cukup } & \multicolumn{2}{|c|}{ Kurang } & & & \\
\hline & $\mathbf{n}$ & $\%$ & n & $\%$ & $\mathbf{N}$ & $\%$ & \\
\hline Tangibles (Physical Evidence) & & & & & & & 0,003 \\
\hline Enough & 133 & 86,4 & 21 & 13,6 & 154 & 100.0 & \\
\hline Less & 126 & 73.1 & 47 & 26,9 & 175 & 100.0 & \\
\hline Total & 261 & 79,3 & 68 & 20,7 & 329 & $\mathbf{1 0 0 . 0}$ & \\
\hline Reliability & & & & & & & 0,004 \\
\hline Enough & 116 & 87.2 & 17 & 12.8 & 133 & 100.0 & \\
\hline Less & 145 & 74 & 51 & 26 & 196 & 100.0 & \\
\hline Total & 261 & 79,3 & 68 & 20,7 & 329 & 100.0 & \\
\hline Assurance & & & & & & & 0,022 \\
\hline Enough & 117 & 85.4 & 20 & 14.6 & 137 & 100.0 & \\
\hline Less & 144 & 75 & 48 & 25 & 192 & 100.0 & \\
\hline Total & 261 & 79,3 & 68 & 20,7 & 329 & 100.0 & \\
\hline
\end{tabular}

Source: Primary Data, 2020

Based on table 2 it can be seen that from 154 respondents who stated Tangibles (physical evidence) was sufficient, there were $133(86.4 \%)$ who stated that the quality of service was sufficient and $21(13.6 \%)$ stated that the quality of service was lacking. While 175 respondents who stated Tangibles (physical evidence) was lacking, there were $128(73.1 \%)$ who stated that the quality of service was sufficient and there were $47(26.9 \%)$ who stated the quality of service was lacking. From the Chi-Square test results obtained $p$-value $=0.003$ indicating $p>\alpha(0.05)$ which means that there is an influence of Tangibles (Physical Evidence) between Perception and Expectations on the Quality of PostAccreditation Outpatient Health Services in the Puskesmas Sulewana, Poso Regency.

Based on the Reliability variable in table 2 it can be seen that from 133 respondents who stated that Reliability was sufficient, there were $116(87.2 \%)$ who stated that the quality of service was sufficient and $17(12.8 \%)$ which stated the quality of service was lacking. While from 196 respondents who stated that Reliability was lacking, there were 145 $(74 \%)$ who stated that the quality of service was sufficient and there were $51(26 \%)$ who stated that the quality of service was lacking. From the Chi-Square test results obtained $p$-value $=0.004$ indicates $p>\alpha(0.05)$ which means that there is an effect of Reliability between the Perception and Expectations on the Quality of Post-Accreditation Outpatient Health Services in the Puskesmas (Community Health Center) Sulewana, Poso Regency.

Based on the Assurance variable in Table 2 it can be seen that from 137 respondents who stated Assurance was sufficient, there were $117(85.4 \%)$ who stated that the quality of service was adequate and $20(14.6 \%)$ which stated that the quality of service was lacking. While from 192 respondents who stated Assurance was insufficient, there were 144 $(75 \%)$ who stated that service quality was adequate and there were $48(25 \%)$ who stated that service quality was lacking. From the Chi-Square test results obtained $p$-value $=0.022$, indicating $p>\alpha(0.05)$ which means that there is an effect of Assurance Between Perception and Expectation on the Quality of Post-Accreditation Outpatient Health Care Services at the Puskesmas Sulewana, Poso Regency

\section{DISCUSSION}

This research shows that there is an effect of physical evidence, reliability, and guarantee (on the quality of postaccreditation outpatient health services in the Poso Regency sulewana health center [4] tangible includes the physical appearance of services, such as physical facilities, tools, or equipment, and also the appearance of workers. According to Eshetie et al. [5], Tangible can be seen from the atmosphere and general appearance of physical facilities, rooms, restaurants, communication equipment, and employees.

In the physical appearance of facilities, equipment, personnel, and materials used in communicating with consumers. Which consists of: cleanliness, place, atmosphere, appearance of service and location. From the theories that have been presented, it can be concluded that tangible is one of the assessment factors for consumers based on physical appearance, both facilities, equipment, hygiene, and puskesmas staff [6].

Tangibles variable (physical evidence) the majority of respondents feel sufficient about tangibles variable in the form of room conditions where the puskesmas (Community Health Center) building pays attention to the function, safety, and convenience in health services, with the availability of rooms according to the needs of available health services, the rooms that must be available according to the minimum puskesmas accreditation standards are registration room and 
waiting room, administration room, examination room, doctor's consultation room, action room, pharmacy room, ASI room, bathroom and toilet, and other rooms according to service needs, and the appearance of officers must be guided by the values, vision and mission of the puskesmas. This research is in line with Lontaan et al. [7] where the reliability dimension goes well, and this makes patients feel satisfied with the quality of health services

Felix [8] states that reliability is reflected in providing services as promised in a timely manner and can handle problems well. Reliability is the ability of an institution, organization, or employee to provide services quickly and accurately Bharwana et al. [9]. Reliability can be measured in terms of speed, desire to respond, accuracy, and can be relied on. Based on these theories, it is concluded that reliability is the ability to perform services that are accurate in accordance with the conditions and can be relied upon [6].

Chapter I Accreditation Standards for Puskesmas (Community Health Center) Services (PPP). Analysis of community needs and puskesmas planning. Community needs for puskesmas services are identified and reflected in puskesmas efforts. Opportunities for the development and improvement of services are identified and outlined in the planning and implementation of activities. Implementation of this criterion will have an impact on the improvement in the reliability dimension.

Reliability variable (majority) the majority of respondents felt sufficient about the reliability variable in the form of the ability to carry out the promised service with an accurate and reliable attitude, service delivery and puskesmas efforts supported by a working mechanism to achieve the needs and expectations of service users, implemented efficiently, precisely time, minimizes errors and prevents delays in implementation.

Sulewana Puskesmas with the main accreditation status wherein the standard achievement of accreditation chapters chapter I scored $\geq 60 \%$. From the results of the study on the reliability variable that there is an influence on the quality of service, where there is an influence on the main dimensions of service based on tangibles (physical evidence) between perceptions and expectations of the quality of post-accreditation outpatient health services. To maintain and improve the quality of health services towards a complete accreditation with a standard value of $\geq 75 \%$ all elements of the assessment are fulfilled, then the sulewana puskesmas must be responsible for planning, monitoring, and evaluation of each element of the puskesmas accreditation standard assessment.

This research is in line with Wahidah et al. [10] shows that there is a relationship of reliability with patient satisfaction. Other research conducted Saputra et al. [11] shows that respondents who expressed satisfaction with the quality of service in RSDI (Special Region Hospital) Banjarbaru City by $40.0 \%$ considered that the majority stated that the reliability was good.

Assurance means customers feel safe in transactions, consistent employee courtesy, and the ability of employees to answer every customer question [8]. Likewise, a statement from [4] that assurance includes competence, courtesy, credibility and security, employee awareness and courtesy, and the ability of employees to build customer trust and confidence. Likewise, stated by Bharwana et al. [9] namely awareness of the politeness of employees and their potential to build self-esteem as well as customers. The conclusion of assurance theories is the knowledge and ability that employees have to build the trust and confidence of customers.

Chapter III accreditation standards on improving the quality of puskesmas (PMP). Improving the quality and performance of puskesmas (Community Health Center) is consistent with the values, vision, mission, and goals of puskesmas, understood and implemented by puskesmas leaders, those responsible for puskesmas efforts and implementers, will have an effect on improving the assurance dimension. to the assurance variable relating to the knowledge and ability of employees to build trust and confidence from customers.

Improving the quality of performance will support the knowledge and ability of officers to build customer trust, improving the quality of performance of health centers must be consistent with the values, vision, mission, and goals of health centers, understood and implemented by the leadership, responsible for the effort and implementer. Sulewana Puskesmas with the main accreditation status wherein the standard achievement of accreditation chapters chapter III scored $\geq 60 \%$. From the results of research on the assurance variable that there is an influence on service quality, where there is an influence on the main dimensions of service based on assurance (assurance) between perceptions and expectations of the quality of post-accreditation outpatient health services.

Research conducted Saputra et al. [11] shows the majority of respondents rated comfort/guarantee is good where the percentage of statements satisfied with the service is proportional to the high percentage of good guarantee ratings by respondents. This is in line with research conducted by Muhith et al. [12] that the majority of respondents stated that they were kind to the guarantee dimension at the Dekongan District Health Center in Lamongan. 
To maintain and improve the quality of health services towards a complete accreditation with a standard value $\geq$ $75 \%$ of all assessment elements are met, the sulewana puskesmas are required to continuously improve performance by planning, monitoring, and evaluating each element of the puskesmas accreditation standard assessment.

\section{CONCLUSION}

Based on the results of research and discussion of data collected, there is an influence of physical evidence ( $p=$ $0.003)$, reliability $(p=0.004)$ and guarantee $(p=0.022)$ on the quality of post-accreditation outpatient health services at the puskesmas (Community Health Center) sulewana Poso Regency. It is expected that health workers so that the procedure for admitting outpatients in the administration section of the Puskesmas Sulewana, Poso Regency will not be complicated (fast) and to further improve the quality of health services towards plenary accreditation, by further enhancing the quality of the tangibles dimension that has an impact on chapter II, dimensions The reliability of impact in chapter I, and the assurance dimension impact on chapter III of the puskesmas accreditation standards.

\section{REFERENCES}

1. Bustami. (2011). Penjaminan Mutu Pelayanan Kesehatan \& Akseptabilitasnya, Jakarta, Erlangga.

2. Regulation of the Minister of Health of the Republic of Indonesia. (2015). Peraturan Menteri Kesehatan Republik Indonesia Nomor 46 Tahun 2015 Tentang Akreditasi Puskesmas, Klinik Pratama, Tempat Praktik Mandiri Dokter, Dan Tempat Praktik Mandiri Dokter Gigi. Jakarta: Kementerian Kesehatan.

3. Profile of Community Health Centers. (2019). Profile of Community Health Centers Sulewana Kabupaten Poso Tahun 2019. Kabupaten Poso: Puskesmas Sulewana.

4. Albarq, A.N. (2014). Measuring The Impacts Of Online Word-Of-Mouth On Tourists' Attitude And Intentions To Visit Jordan: An Empirical Study. International Business Research, 7(1):14-22

5. Eshetie, S. K., Seyoum, W., \& Ali, S. H. (2016). Service quality and customer satisfaction in hospitality industry: The case of selected hotels in Jimma Town, Ethiopia. Global journal of management and business research.

6. Donkoh, S., Quainoo, A., Cudjoe, E., \& Kaba N. (2012). Customer Satisfaction And Perceptions About Food Services On The University For Development Studies Campus, Ghana, 6(8):216-223

7. Lontaan, V., Rumayar A.A., \& Tucunan A.A. (2019). Hubungan Antara Persepsi Pasien Terhadap Mutu Jasa Pelayanan Kesehatan Dengan Kepuasan Pasien Rawat Jalan Di Puskesmas Ratahan Kabupaten Minahasa Tenggara. Kesmas, 7(5):1-8

8. Felix, R. (2017). Service Quality And Customer Satisfaction In Selected Banks In Rwanda. Journal Of Business \& Financial Affairs, 6(1):246-256.

9. Bharwana, T. K., Bashir, M., \& Mohsin, M. (2013). Impact of service quality on customers' satisfaction: A study from service sector especially private colleges of Faisalabad, Punjab, Pakistan. International Journal of Scientific and Research Publications, 3(5), 1-7.

10. Wahidah, R., Sudirman, S., \& Andri M. (2019). Hubungan Mutu Pelayanan Kesehatan Dengan Kepuasan Pasien Puskesmas Birobulikecamatan Palu Selatan Kota Palu. Jurnal Kolaboratif Sains, 1(1)

11. Saputra, A., \& Ariani N. (2019). Hubungan Mutu Pelayanan Kesehatan Dengan Kepuasaan Pasien Rawat Jalan Pengguna Kartu Bpjs Di Rumah Sakit Daerah Idaman Kota Banjarbaru. Borneo Nursing Journal (BNJ), 1(1):48-60.

12. Muhith, A., Siyoto, S., \& Rahmah R.E. (2017). Hubungan Karakteristik Pasien Pengguna Kartu Bpjs Dengan Persepsi Tentang Kualitas Pelayanan Kesehatan Di Puskesmas Deket Kabupaten Lamongan. Medica Majapahit, 9(1)73-83. 